TRANS · NÚM. I2 $\cdot 2008$

DOSSIER $\cdot 67-79$
Este artículo estudia las marcas de catolicismo encontradas en la traducción de textos religiosos por el misionero jesuita José de Anchieta (1534-1597) en Brasil durante el siglo Xv. El estudio muestra cómo Anchieta empleó en sus traducciones términos del mundo espiritual de los Indios Tupi como «equivalentes» de terminos cristianos para evangelizar pero no buscó entender su significado profundo. Se establece un paralelismo entre la voluntad de Anchieta de mezclar términos cristianos con conceptos del mundo espiritual de los indios brasileños, y la "equivalencia dinámica» de Eugene Nida así como los conceptos de "naturalización» y «extranjerización» de Lawrence Venuti. El artículo termina examinando las obras de Anchieta y los asentamientos religiosos conocidos como Santidades estrechamente vinculados con la identidad católica hibrida predicada por los jesuitas.

PALABRAS CLAVES: José de Anchieta, aculturación, inculturación. Jesuitas, traducción de textos religiosos.

\title{
The mixed identity of the Catholic religion in the texts translated by the Jesuit priest Jose de Anchieta in I6th century Brazil
}

Paulo Edson Alves Filho

Universidad de Sorocaba, Brasil John Milton

Universidad de Sao Paulo, Brasil
This article will examine the characteristics of the Catholicism found in the translation of religious texts by the Jesuit missionary José de Anchieta (1534-1597) in Brazil in the 16th century. The study will show that Anchieta used terms from the spiritual world of the Tupi Indians in his translations as "equivalents" for Christian terms as a way of introducing Christianity but made no attempt to understand the deeper meaning of these terms. We make a parallel of Anchieta's readiness to mix Christian Catholic terms and concepts from the spiritual world of the Brazilian Indians with the "dynamic equivalence» found in the work of Eugene Nida and the concepts of domestication and foreignization found in the work of Lawrence Venuti. The article will also examine the writings of Anchieta and the religious settlements called Santidades, which were closely related to the hybrid identity of Catholicism preached by the Jesuits. KEYWORDS: José de Anchieta, acculturaltion, inculturaltion. Jesuits, religious translation. 
THE ARRIVAL OF THE JESUITS IN BRAZIL

In 1500, when Pedro Álvares Cabral arrived in 68 the lands that would be called Brazil, a mass was promptly celebrated. This fact shows that the Portuguese Crown and the Catholic Church were partners in the enterprise of colonizing this part of South America. The Portuguese, still in the atmosphere of the Crusades, had the Cross of the Order of Christ painted on the sails of Cabral's fleet.

They landed in what is the modern-day state of Bahia, but the main town they founded was São Vicente, in what is now the state of São Paulo, over a thousand kilometers further south down the coast. There, Manuel da Nóbrega, a leading priest of the Society of Jesus, started his activities of teaching and catechizing the Tupi Indians. The main impression of the Jesuits was that the Indians neither had any religion nor worshipped any deity or god.

It did not take long for the Portuguese to change their minds: as soon as they were in contact with the Indians' anthropophagical rituals they realized that these rituals were closely connected to the Devil.

From 1543 on the Jesuits were simultaneously engaged in delivering the message of God and erasing the Indians' ancient habits. In order to carry out this complex task, Nobrega depended on other members of the Society, among them the prominent priest, José de Anchieta, who was the most important translator of the liturgy used for catechizing the natives. Both Nobrega and Anchieta had the missionary task of gathering the Indians in villages and, through preaching, bringing them close to the true Catholic faith. Besides this, they would fight polygamy and nudity among other so-called 'barbarian' ways of the Indian daily lives.

Differently from the Jesuits, the Indians were also subject to the colonizers, known as mamelucos ${ }^{\mathrm{I}}$, as they were seen as a potential slave workforce for the large sugar cane farms and mills along the coast. From the contact with mameluco and Portuguese colonizers the Indians were subjected to slavery and mistreatment. It can be said that the colonizers were interested in their bodies, their potential as a labour force, whereas the Jesuits were interested in their souls².

\section{THE JESUIT TRANSLATIONS TO TUPI: A MIXING OF CULTURAL PATTERNS}

in $\mathrm{I555}$, three years after arriving in Brazil, Jose de Anchieta supervised a meeting with other «Lingoas» (Jesuits who spoke Tupi fluently) in Sao Vicente, in order to normalize the terminology used in the Dialogues and Speeches addressed to the Indians. By this time Anchieta had learnt and mastered Tupi and translated texts such as the Roman Catechism, primers, parish manuals, spiritual exercises, poems and didactic plays.

In order to make these translations, Anchieta tried to transfer a set of concepts from his culture to Tupi. Due to the enormous difference between both cultures, the results were often unexpected, as Alfredo Bosi (1992:65) states:

«In the passage from one symbolic sphere to another, Anchieta found obstacles which at times could not be solved. How could the Tupi Indians be told about the word 'sin' if they had no such notion, at least according to what was registered throughout the Middle Ages in Europe?»3

I Mameluco, word from the Arabic, memluk, «slave», the household cavalry of the former sultans of Egypt. A general term applied in South America to designate the mixed European-Indian race.

2 For a broader discussion on the intentions of European colonizers in Brazil, see Schwartz I988.

3 «Na passagem de uma esfera simbólica para a outra 
Anchieta frequently tried to look for some corresponding element in two languages with unequal results (op. cit., p. 67) as, for instance, translating «angel» as «karaibebe», or «a flying shaman» or «devil» as 'Anhangá', whose original meaning for the Tupi Indians was the supernatural entity that protected the animals and the jungle. Through the speech of Anhangá in his plays he observed the Indian rituals and behavior (i.e., anthropophagy, polygamy, communication with the dead) as devilish.

Anhangá was not exactly an evil entity (evil as per the European definition), but a mutable being that could take on a number of identities in order to entrap humans.

Manipulating and translating elements like these, Anchieta tried to reorganize their place in the Tupi imaginary. In order for the Manichean-European religious perspective to be inserted in the Indian religion, Tupa a (originally meaning the thunder god) would need an opposite force to represent the dark side and the Devil, which Anchieta would name Anhan$g a ́$, who, according to the Indian imaginary, was the protector of the jungle and animals and had amazing powers and skills, and was able to shift form and shape and torment human beings. In this new model introduced by the Jesuits, the powers of Anhangá were increased: he would take on the role of Prince of the Darkness and would be directly responsible for all bad habits of the Amerindians such as cannibalism, polygamy, drunkenness from cauim ${ }^{4}$, and all other «devilish» rituals for European eyes. Indeed, Anchieta might have made this choice as a result of the fear Anhangá inspired in the nati-

Anchieta encontrou óbices por vezes incontornáveis. Como dizer aos tupis, por exemplo, a palavra pecado, se eles careciam até mesmo da sua noção, ao menos no registro que esta assumira ao longo da Idade Média européia?»

4 Wine made of fermented corn. ves rather than for its diabolical essence.

Bosi (op.cit., p. 69) states that the most efficient method of destroying the bad habits of the Indians was quickly discovered: generalizing fear among the natives and extending it to all entities that might appear in the native trances and ceremonies, demonizing any events that facilitated the path for the return of the dead. At the time of the arrival of Europeans in Brazil witches and sorcerers were persecuted all over Europe. The imaginary of the men from Europe on American soil was dominated by the vision of parallel forms of religion, i.e., pagan worship, and thus the tendency was to interpret the worship of the Indians as a kind of «demonolatry». In the same way that in Europe, pagan rituals and worship were condemned and suppressed, in America the Europeans had to exterminate the tradition of paganism (Mello e Souza, 1993).

It is no surprise that Anchieta chose the Devil as the most common character in his plays. Through the Devil's speech, he would portray Indian rituals and behavior as devilish, criticizing them and delivering a strong message against them. Cannibalism and polygamy were key elements for the Indians' social lives, and were the elements which most appalled the missionaries. But the Indians did not relate them to Anbangá. Cannibalism was the result of warfare and important for the tribe's supremacy over their enemies. A prisoner of war would be kept for several months, treated well and sometimes given a wife. But on an appointed day he would be killed and prepared for a feast. Old women drank his blood and mothers smeared it over their breasts. The body was roasted and eaten by the entire village and their guests. If the prisoner had been given a wife, she wept for him, but then she also joined the feast. The executioner was forbidden to feast 
and had to stay in seclusion to protect himself and the village from the prisoner's ghost. This cannibalistic treatment given to the enemy was justified for two reasons: revenge and incorporation of the brave soul of the enemy into the executioner's own soul.

Likewise, polygamy was a useful and meaningful practice for daily tribal life: while one woman was working out in the field the other (or others) would look after the children and work in the village.

The complex task of translating these new elements would show how different the cultures involved in the process were, especially in linguistic terms. From the Jesuit point of view, Tupi was basically a concrete language, lacking the range of words to describe abstract concepts and ideas of Portuguese (or any other European language).

Along with the new terms, the European introduced an array of new practices, instruments and intentions, which eventually also provided the Indian language with neologisms. It was the case of karaibebé (angel). The conception of a flying shaman was very different to the biblical definition. The same may be said about the word «sin», which Anchieta chose to render in Tupi as "tekó-aíba», «tekó-poxy", or «tekó-angaipaba» (bad life, bad culture of a people). The definition itself of «sin» would imply a broader range of concepts. As it usually refers to a transgression of God's will or any of the godly laws or principles, it would not mean «bad life» according to indigenous parameters, but rather according to European ones. Therefore, «sin», translated as «bad life» would have a rather diffuse sense for the Indians, as it lacked a prior acknowledgement of God's will. Another neologism created by Anchieta, which contains the missionary id eology, is «moropotar-e'yma» (not desire someone sexually) used for rendering the word "purity», thus erasing any Christian concept of "purity».

Similarly to missionary translations in the Phillipines, as noted by Rafael (I988:20-2I), Anchieta chose to keep some words in Portuguese, such as 'domingo' (Sunday), 'Virgem Maria' (Holy Mary), 'Santa Igreja' (Holy Church), 'tentação' (temptation) and 'reino' (kingdom). In this way, the Christian flow of discourse in Tupi was interspersed with alien language. Some examples are as follows:

\section{«Eimoeté Domingo» 5}

(Keep Sunday holy)

Orê rûb Ybàkupe tekóar, Ymoete pyramo,nde rera toikó Tour nde Reino ${ }^{6}$

(Our Father, who art in Heaven, Hallowed be thy name. Thy kingdom come)

\section{Oré mo'ar-ukar ume iepé tentação pupé 7 (Lead us not into temptation)}

If the insertion of Portuguese words in the Tupi speeches points to how inadequate the native language was to express God's will, such a flaw would be repaired through reformulating the Tupi and through embedding a new vocabulary with foreign words in it, so it was now considered by the colonizer to be more suitable for transmitting the precepts of $\mathrm{God}^{8}$.

In addition to the Tupi language, the native culture was also manipulated by Anchieta. His plays mixed Iberian drama, Catholic precepts and Indian rituals. All these source elements

Anchieta, I992:I43.

6 Navarro, 200I: 62 .

Op. cit., p. 63.

8 In order to illustrate his argument, Rafael gives a number of examples of words kept in Spanish such as Dios, Spiritu Santo and Jesu Cristo. 
were translated / rewritten in order to work in favor of his missionary purposes.

Ultimately, the beginning of a hybrid culture was partly due to the translation of elements from the "other» being intelligible in linguistic but not in conceptual terms. The missionary translation inserted a new organizing matrix into the Indian imaginary and also provided new values for familiar elements to the native, thus collaborating in the creation of a religion with a new identity, i.e., an Indigenous Catholicism.

In order to examine the choices in Anchieta's translations, we can look to the theories of Eugene Nida and Lawrence Venuti.

Formal and dynamic translation: Eugene Nida and Anchieta's strategies.

Eugene Nida, in Toward a science of translation, notes that translators exist between the pressures of form and content: privileging stylistics, the translator may distort meaning; privileging meaning, he or she may lose the stylistic elements. Anchieta's works feature a linguistic attempt to make the terms familiar to the natives (i.e., using neologisms for new concepts or using Tupi words to render new concepts and thus performing a translation which is closely related to what Nida calls «formal equivalence».

This is the case with the following extract:

Ndiapysýkixópemo serobiasára opyápe ñóte serobiámo? 9

(Was not it enough that the believer would believe only in his heart?)

"O mba'e, n’ipó, asé o py'a pupé s-âेsub-i» 1о

(Their own things, truly, we love with our heart)

9 Opyápe: the word «pe» equals to the preposition «at». Opyá, in literal translation, is liver. In: Anchieta, I988:Irg. Seleção, notas e introdução de Eduardo de Almeida Navarro.

ro «Auto de São Lourenço», v.306. In: Anchieta, r999.
If we literally back translate this dialogue, we would have: «their own things, truly we love in our liver». The word "py'a» refers to «heart» in a figurative sense, as in the Tupi culture the organ 71 related to feelings was the liver (py'a). This is a good case of dynamic equivalence. Nida (I964:I58) says the "translator's purposes may involve much more than information. He may, for example, want to suggest a particular type of behavior by means of a translation. Under such circumstances he is likely to aim at full intelligibility, and to make certain minor adjustments in detail so that the reader ${ }^{\mathrm{II}}$ may understand the full implications of the message for his own circumstances».

When Anchieta employs the word "py'a» (liver) for «heart», he is using dynamic equivalence, which aims a natural expression for the listener / reader. Some other examples of dynamic equivalence in Anchieta's translation are God (Tupã), baptism (imongaraib) and devil (Anhangá), but, paradoxically, these helped to distort the message as «baptism» and «imongaraib» ${ }^{12}$, «God» and «Tupã» are not culturally equivalent.

According to Nida, the translation should render the closest equivalent in the target language to the original message. Nida applies the terms «equivalent» (towards the message in the source language), «natural» (towards the target language to complete the comprehension of the receptor culture and audience) and «closest» (which is a mixture of both). For Anchieta, it seems that the nearest «closest equivalent of» God was Anhangá.

A natural translation might imply two types of adaptation: grammatical and lexical. The

II In the case of Anchieta, the hearers.

I2 literally means «something made enchanted or bewitched by water». 
grammatical adaptation is ruled by the structure of the target language whereas the lexical may be divided in three sub-areas:

I) those that involve terms with immediate equivalence. In the case of Tupi, they are, for example, «hand» $(p o ́)$, «water» $(y)$, «man» $(a b a \hat{a})$, «sky» $(y b a k a)$, etc.

2) those that involve terms for identifying objects culturally different but with the same functions: «hell's fire» (añanga rata ${ }^{\mathrm{r} 3}$ - literally: Anhangá’s fire), «church» (tupã okupe $e^{14}$ - Tupã’s house), «heart» (pya ${ }^{15}$ - liver), etc.

When rendering the message into Tupi through lexical adaptation, Anchieta changed the definitions and thus added to the infidelity of the text in terms of the original.

3) those that involve specifications of the culture: «Christians $»^{16}$, «Holy Cross» ${ }^{17}$, «sin $»^{18}$.

Anchieta most often kept these words in Portuguese.

«Usually the first set of terms involves no problem. In the second set of terms several confusions can arise; hence one must either use another term which reflects the form of the referent, though not the equivalent form, or which identifies the equivalent function at the expense of formal identity. (...) In translating terms of the third class certain 'foreign associations' can rarely be avoided. No translation that attempts to bridge a wide cultural gap can hope to eliminate all traces of the foreign setting. (...) It is inevitable also that when source and receptor languages represent very different cultures there should be many basic themes and accounts which cannot be 'naturalized' by the process of translating» (Nida, I964:I68).

\footnotetext{
Anchieta, I988.

Ibidem.

Ibidem.

Ibidem.

7 Ibidem.

I8 Ibidem.
}

In many instances Anchieta tries to explain the foreign words inserted in his translations. This is the case of his «Diálogo da Fé» (Dialogue of Faith), which usually introduced Christian concepts and subsequently offered an explanation to the listener:

«M:Marã ybyrá supénéépe asé jerokýu?

(M: Should we compliment the wood somebow?)

D: Aáni; saangábijära supéé, sesé omanenduáramo

(D: No, but we do have to compliment it having in mind what it refers to)

M: Abápe Cruz raangábijára?

(M: What does the Cross mean?)

D: Jandé Jára Jesu Cristo

(D: [It means] Our Lord Jesus Christ)

M: Maránamope?

(M:Why?)

D: Sesé imojáripýramo omanómo ojemoatãáguéra rese $e^{19}$.

(D: Because he was crucified on it and there he died)

This passage shows Anchieta's effort to show Christian meanings to the natives. The cross («cruz» in Portuguese) is justified by its relation to Jesus Christ.

\section{FOREIGNIZING AND DOMESTICATING TRANSLATIONS IN ANCHIETA'S WRITING}

Lawrence Venuti, in The Translator's Invisibility, shows evidence of foreignizing and domesticating translations throughout history and theoretical studies of translations in the West. He claims that translation has been used

19 In: Anchieta, I988:122. 
as a tool of conquest since, at least, the Roman Empire. In order to illustrate his point he states that Roman translators of Greek works not only excluded Greek cultural markers but also added allusions to Roman culture in their renderings, replacing names of Greek poets by Roman ones in order to give the impression that the texts were originally written in Latin.

Venuti says that the domesticating method in translation, which has many similarities to Nida's dynamic equivalence, is an ethnocentric reduction of the foreign text into the target language's culture and values, thus resulting in a fluent translation (Venuti, 1995:20). This reduction turns the text into something easily understood, made in the standard language of the target culture instead of a variant discourse.

The concept of foreignizing translation privileges the foreign text, approximating elements of the text to the foreign culture (op. cit., p. I46). According to Venuti, the foreignizing translation might have the following features:

a) it follows syntactical, lexical or rhythmical elements of the foreign text;

b) it maintains foreign cultural markers;

c) it creates dialectal variations in the language of the target culture, such as stylistic innovations, neologisms and literary figures of speech such as metaphors.

Venuti mentions his own translation of the poems by the Italian writer Milo De Angelis which challenged the dominant Anglo-American aesthetics in order to reproduce the discontinuity and indetermination of the origina ${ }^{20}$.

${ }_{20}$ De Angelis writes:

"Esseri dispotici regalavano il centro

distrattamente, com una radiografia,

${ }^{\circ}$ in sogno padroni minacciosi

sibilanti:

se ti togliamo ciò che non è tuo

non ti rimane niente'."

The translation by Venuti foreignizes the text due to its
Anchieta also uses similar solutions in parts of his work, maintaining literality when translating into Tupi. The comparison of the flow of discourse between Anchieta's writings and the letter of Diogo Camarão ${ }^{2 \mathrm{I}}$, the only surviving (or existing) letter written in Tupi by an Indian, shows a similar foreignizing strategy, following the parameters proposed by Crofts (1974) related to differences between the Tupi language and Portuguese. Hansen (2005:33) ${ }^{22}$ also observes the foreignizing strategy in Anchieta as he tries to imprint Portuguese rhymes, rhythm and metre onto Tupi.

The definition of domesticating translation from Venuti's point of view is that it is a transparent and fluent translation which eliminates the linguistic and cultural difference of the original in the target culture and is often rewritten with the social representations, beliefs and values of the target culture (Venuti, I995:38).

Using Venuti's hypothesis, we can find in parts of Anchieta's plays a 'transparent' translation, providing the audience (Indians and colonizers) with a fluent message from the characters. Anchieta had strong influence from the works of Gil Vicente (1465-1537), one of the most important Portuguese dramatist. His

peculiar syntax and aesthetic compared to those dominant in English poetry:

"Despotic beings made a gift of the center

absentmindedly, with an X-ray,

and in a dream threatening bosses

hissing:

'if we take from you what isn't yours

you'll have nothing left'.»

op. cit., p. 29 I.

${ }_{21}$ Letter written by Diogo Camarão to his cousin, $\mathrm{Pe}-$ dro Poty, in I645. in Navarro, I999:530.

${ }^{22}$ «Metrificar o tupi com a redondilha menor medieval impóe uma acentuação, um ritmo e a forma de respiração européia que o aculturam. Rimar o tupi submete a lingua do indigena a um sistema musical de equivalências relacionadas ao principio de similitude e, portanto, ao princípio metafísico de identidade, Deus.» in Hansen, 2005:33. 
plays and poetry, written in Portuguese and Spanish, reflected the changing times during the transition from Middle Ages to Renaissance and their themes, ideology and structure are clearly reflected on Anchieta's works.

Anchieta's play Auto de São Lourenço (Play of Saint Lawrence) features characters such as Guaixará, Aimbirê e Sarauaia who are enemy Indian leaders. At the beginning of the Second Act, Guaixará is welcome by an old Indian woman with a traditional 'tearful compliment ${ }^{\prime 23}$. Among characters known by the audience, there are others only known by the Europeans, such as Saint Sebastian and Saint Lawrence.

On one hand, Anchieta domesticates his translations by using familiar terms and does not force the audience to acknowledge the cultural patterns of the source language. But on the other, he takes advantage of this domestication in order to insert elements of the source culture into the Indian culture. This intervention has been one of the main characteristics of his catechizing. Both strategies are described by Schleiermacher (2004) who claims that the translator can choose from two options: either he leaves the author in peace, foreignizing the translated text, or leaving the reader in peace, domesticating his production. In the case of colonial Brazil, one can see reader as representing the colonized, and the author as the Jesuit. As examples of such translated texts, the plays Auto de São Lourenço (Play of Saint Lawrence) and $\mathrm{Na}$ aldeia de Guaraparim (at Guaraparim Village) feature both domesticating and foreignizing translations:

\footnotetext{
23 "saudação lacrimosa», in which the women of a tribe compliment the host, weeping and telling them about bad events which took place in their community.
}
«Kûeîsé kó a-por-apiti ầuruîuba îukábo,
$\hat{u} i$-nhe-moerapîa $\tilde{a}$-ngat $\hat{u}-a b o$
T'a-só nde pyr-y, kori,
Aîpó t-ubixaba gîu-abo» ${ }^{24}$

(Yesterday I slaughtered people,

Killing the Europeans,

I became very famous.

I ought to go to you, today,

To eat those kings)

In the speech of the devil Kaburé, Anchieta uses the term «aîuru-îuba» to render - in a domesticating translation - «Europeans». This word in Tupi literally means «yellow parrots», which was used in a negative sense by some Indians for referring to the French and the English.

In this extract from the play $\mathrm{Na}$ aldeia de Guaraparim, Anchieta chooses the foreignizing translation, keeping the Portuguese term «cristão» (Christian) instead of choosing another explanatory term or expression in Tupi:
S-emo'é, oiobaupa.
Xer-erok-etépa'i.
A-royró-mbá t-ekó-poxy,
Abaré nhe'eng-endupa.
Xe cristão, xe karaí. ${ }^{25}$
(They lie, to each other.
I was truly christened by the priest.
I completely hate sin,
Listening to the priest's word.
I am Christian, I am virtuous.)
In the same play, we can find both foreigni-

\footnotetext{
24 «Auto de São Lourenço» V.766-770. In: Anchieta, I999.

${ }_{25}$ « $\mathrm{Na}$ aldeia de Guaraparim» V.503-507, op.cit.
} 
zing and domesticating translations:

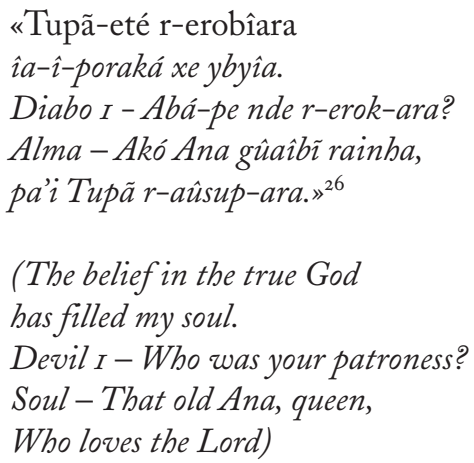

The expression ' $r$-erok-ara' means 'who has erased the name' (referring to the fact of replacing it by another Christian name) and is directly related to the role of a 'patroness'. However, Anchieta does not worry about finding an equivalent in Tupi for the expression 'rainha' (queen, in Portuguese).

In his translations and writings in Tupi, the social representations, beliefs and values of the target culture are reorganized with the intention of introducing the European cosmology into the life of the Indians. Anchieta manipulates these elements in favor of his mission and blends them with exotic and alien elements for his audience, thus creating a religion with an identity which had elements borrowed from both the European and the Indians.

\section{INCULTURATION TO PROMOTE THE ACCULTURATION OF THE INDIANS}

When trying to classify the Indians by using the realms of Heaven and Hell, the Europeans were projecting their own European ideas and identity onto them, in other words, seeing the

26 Op.cit., V. 508-512.
Indians as their shadows as they brought their «own Lucifer in the bilge of their ships» ${ }^{27}$. In ethnological terms, the colonizers seemed not to be aware of the concept of «Otherness». For instance, the Devil seemed to be extraneous for the Mayas, Aztecs and Tupis. The deities of the native were neutral, neither good nor bad, very different to the Christian God. They would not fit at all into the European dialectical vision of the universe, in which opposite forces were seen as reciprocal and complementary. The Indian entities did have massive and destructive powers but were hardly related to whatever the Christians considered, for example, as «devilish». However, Anchieta attempted to fit them into the Christian scheme. This inculturation, the mixing of Christianity and the Tupi Indian spiritual world, remained at a merely superficial level, and the Indian deities were also reshaped by being given Christian qualities. The original Jewish God brought by the Portuguese and named Tupã in the conversion-translation made by the Jesuits, would take on a new status: it would be the supreme god, would have a mother (Tupansy - Holy Mary), who would also be its daughter and would have a house and a kingdom (Bosi, 1992:67).

In the list of other «unequal» translations that configure an inculturation of the method of catechizing the Indians, Navarro (200I) exemplifies the expressions rata (the fire of Anhangá, related to the «inferno», a definition of a place of eternal suffering, a concept totally extraneous for the native) and moro-potar-e'yma (literally: «not to desire people sensually»), which, as previously mentioned, would be used for "purity», an expression loaded with ideology (in this case, the most suitable way of disagree-

\footnotetext{
27 «...seu próprio Lúcifer que haviam levado do Velho Mundo nos porões de seus navios.» In Vainfas, 1995:25.
} 
ing with the Indians' sexual behavior, which hardly followed Catholic principles).

This choice of keeping some words in Por76 tuguese also shows how unsuitable Tupi was for the task of expressing God's truth and, to repair this lack in the natives' language, As mentioned earlier, Tupi itself needed to be reformulated and to incorporate an extended vocabulary with words from the foreign language, considered by the colonizer as superior and thus more suitable to express God's precepts ${ }^{28}$.

Vicente Rafael, discussing the introduction of Christianity into the Phillipines in the r6th century, also points out a hierarchy emerging from this translation chain ${ }^{29}$ (in Robinson 1997: 85): God's Word was suitable in Latin. Spanish, the language of the Empire, was situated one step below, in the case of Colonial Brazil, Portuguese, and less suitable for this purpose. At the bottom of this hierarchy was Tagalog, the native Phillipine language, at the same level Tupi, and it was much less suitable than Spanish for the purpose of expressing the divine truth. Rafael concludes that «the further away from God a language and its culture are, the less able they will be able to participate in 'the divine commerce', the exchange of prayers and answers, gifts and gratitude between God and believers».

Regarding this hierarchy proposed by Rafael, neologisms, such as tupãoka $a^{30}$, were not surprisingly introduced when Catholicism was spread among the Indians. In blending Tupa with $s y^{3 \mathrm{I}}$ (Tupãsy), Anchieta believed he was

${ }_{28}$ Rafael provides some examples of untranslated Spanish words such as Dios, Spiritu Santo and Jesu Cristo.

29 In Robinson, Douglas. Translation and Empire:

Postcolonial Theories Explained. St. Jerome Publishing, 1997, p. 85

3० The blend of the words «Tupã» (God) and «óka» (casa) which meant «church».

3I «Sy» in Tupi means «mother». depicting a clear image of the mother of Jesus. However, he did not translate the term Virgin to Tupi:

\section{(...) morausúberekosar, seémbae Virgem Maria! ${ }^{32}$ \\ (...pious, sweet Virgin Mary!)}

Anchieta's play Recebimento do Padre Marçal Beliarte [The Reception of Father Marçal Beliarte] (1589), features plot and characters clearly based on Gil Vicente's works, with Good always winning. The conversations of the characters are in Portuguese and Tupi, and Anchieta introduces into this representation an important «translated» Indian element familiar within the Indian code of conduct and skillfully diverts it from its original meaning in the native universe of symbols: one of the devils (Makaxera) is killed in a traditional Tupi ritual of cannibalism by a courageous Indian under the command of Tupansy, i.e., mother of Jesus. Shortly before killing the Devil, the Indian Añangupiara says:

$\begin{array}{ll}\text { Kueseñey, Tupansy } & \text { (As before, the } \\ \text { Nde reytyki, nde peabó } & \begin{array}{l}\text { Mother of Jesus) } \\ \text { (has ruined and } \\ \text { smashed you) } \\ \text { (so she has sent } \\ \text { Aéxe mboú kori }\end{array} \\ \text { me here) }\end{array}$

Ko aikó nde akánga kábo (to split your head)

Nei! Ejemosakói

(defend yourself, tough beast)

Tajopune, marandoéra (I will hurt you, false face) (The Indian smashes the Devil's head)

32 Excerpt from the Hail Mary prayer in Anchieta, I992:I48. 
Te! Ajuká Makaxera

Omanongatú moxy

«Añagupiara» xe rerá!
(Ready! I have killed Makaxera)

(Evil does not exist anymore...)

(I am Añagupiara!)

(Anchieta 1999: 245)

With this violent scene, so common in his plays, Anchieta reinforces the Christian message. Though in the ritual proceedings of the Indians the sacrifice of a captive was meant to periodically nourish the virtues of the warriors, in Anchieta's rewriting, this same sacrifice is performed to get rid of the evil. In his «mistranslation» or «rewriting», Anchieta envisions the ritual as a process of «extirpating» rather than «incorporating» since «the words of colonized population can be 'cited' or 'translated' or 'reread / rewritten' by colonizers in way to reframe the colonized culture in the interest of colonial domination» (Robinson,1997:93).

\section{A RESULT OF INCULTURATION: THE SANTIDADES}

By 1591, in the region of the Recôncavo Baiano, near the city of Salvador, Bahia, a settlement of an Indian hybrid religion was founded, whose features were inversions and reinterpretations of what the Jesuits had been preaching during the previous decades. The Santidade do Jaguaripe», as it was called, had Antonio, descendant of Tupinambas, as its leader. He conducted baptisms, assigned «popes», organized rituals, prayer sessions, and was married to Maria Tupansy (literally, the Mother of Christ) (Vainfas, I995:8I). The Indian church kept the belief in the «Land Without Evil» (Yvy Mareiy, in Tupi), the paradise they believed to be within the reach of living humans, over the sea. It also featured the powerful positions of the pope and priest, which were inherent to Catholicism. Although it was declared against the religion of the European, its followers did not cut these entities out of their religion. The movement came to an abrupt end when it attracted the attention of the Santo Ofício de Lisboa, and officers were sent to Bahia and torched the church in 1595 .

The Santidade do Jaguaripe had strategic elements borrowed from what the missionaries preached as the Jesuits themselves used elements from the Tupi cosmology in their writings and practices of delivering the Catholic message. Anchieta's writings and translations had spread to all the places where the Jesuits arrived, and, we can conclude that the santidade form of religion was quite similar to the syncretism found in the process of translating the Christian dogma into the Indian language, as seen in Anchieta's writings.

The examples shown above clearly demonstrate that the inculturated Catholicism practiced by the Jesuits was quite permissive in terms of using the elements of the Indian culture. Anchieta and the Jesuits involved with the missionary work in Brazil did not try to extirpate the supernatural elements of the Indian but rather gave them a new identity in order to acculturate the Indians and introduce them into Christianity. But in the case of the Santidade do Jaguaripe the Tupi Indians inculturate elements of Catholism into native beliefs. This could not be accepted by the Catholic Church.

Although there has been no evidence that the translations made by José de Anchieta were connected to the santidade, both his translations and the movement had similar identities which could be classified as an «Indian Catholicism», an acculturated religion spread either by the Indians (as there are other documented occur- 
rences of santidades in I6th century Brazil) 33 or by the Jesuits themselves.

This «Indian Catholicism» featured concepts that neither belonged to the dogma preached by the missionaries nor to the ancient native beliefs and rituals. Although the latter had clear signs of an anti-colonialist movement, the former was an attempt made by the Jesuits in order to turn the array of cosmological parameters into something understandable and palatable for the Indians.

\section{CONCLUSION}

The missionary work seen in the literary output of José de Anchieta used elements of the Indian cosmology, in varying degrees of deviation from the original sense, in order to spread Christian precepts. In the same way the Catholic Church itself has featured different rites for different peoples since the Roman Empire ${ }^{34}$, one might here claim that the kind of Catholicism the Jesuits practiced in Colonial Brazil was a tailored one, an Indian Catholicism as a result of its terminology and range of meanings deployed in the oral task of preaching the Word of God.

The new identity of the religion that started to be formed in $16^{\text {th }}$ century Brazil had much in common with the interpretation and practice of the Indian santidades. This is due to the efforts of the Society of Jesus to give the Indians the same religious standards as the Europeans. Le Goff and Nora (1976:Ir4) observe that the acculturation cannot be reduced to a simple passage from the Indian culture to western civilization, but there is also an inverse process

33 See Pompa, 2001:189.

34 Examples of different Catholic rites are: Armenian, Chaldaean, Coptic, Georgian, Greek, Melkite, Maronite, Bulgarian, Serbian, Rumanian, Russian, Ruthenian, Malabar, Malankara, West Syrian and Ethiopian.

by which the Indian culture integrates the European elements without losing its original characteristics. This is why the Cuban Ortiz (I940) forged the term «transculturation» to cover both meanings.

The very development of this acculturated identity through partial tolerance of Indian practices and the appropriation of the Tupi codes by the Jesuits to transmit definitions of exotic elements for the local culture in addition to the insertion of Europeans words and practices in the daily village life, might help to explain the santidade phenomenon that took place after contact. It is possible that the Santidade de Jaguaripe shows an interpretation of the Catholicism preached and translated into the vernacular language, under the supervision and guidance of José de Anchieta. The santidade portrayed a part of the Jesuit discourse, which was consolidated in translated texts that moved between foreignization and domestication and did not clearly mark the boundary between Indian and Christian mythology.

RECIBIDO EN ENERO 2008 ACEPTADO EN FEBRERO 2008

\section{REFERENCES}

Alves Fo, Paulo E. (2004). «A colonização espanbola: a sociedade indígena e os modelos propostos pelos teólogos espanhóis do século XVI» in Revista de Estudos Universitários. Sorocaba, v.30, no. 2, p.I4I-I68, junho de 2004 .

Alves Fo, Paulo E and Milton, John (2005). «Inculturation and acculturation in the translation of religious texts: The translations of Jesuit priest José de Anchieta into Tupi in I6th century Brazil» in Target I7: 2, Tel-Aviv, p. 275 - 296.

Anchieta, Pe. José de. (1988). Diálogo da Fé. Introdução histórico-literária e notas do Pe. Armando Cardoso, S. J., São Paulo, Loyola.

Anchieta, Joseph de S.J. (1992). Doutrina Cristã Tomo 
I: Catecismo Brasílico. São Paulo, Edições Loyola.

Anchieta, José (1999). Teatro. São Paulo, Martins Fontes. Seleção, notas e introdução de Eduardo de Almeida Navarro.

Araújo, Jorge de Souza (2003). Pegadas na Praia. Ilhéus, Ed. Da UESC.

Azevedo Fo, Leodegano (I966). Anchieta, a Idade Média e o Barroco. Rio de Janeiro, Editora Gernasa.

Azzi, Riolando (1987). A Cristandade Colonial: um projeto autoritário. São Paulo, Edições Paulinas.

Beall, Stephen M. (I966). Translation and Inculturation in the Catholic Church in Adoremus Bulletin, Vol. II, No. 6: October 1996. online edition: <http://www.adoremus.org/rog6-Beall.html> acessado em 4 de outubro de 2005.

Bosi, Alfredo (1992). Dialética da Colonização. São Paulo, Companhia das Letras.

Cardoso, Armando (1977). Teatro de Anchieta. São Paulo, Loyola.

Crofts, Marjorie (1974). Complexidades Sociolingüisticas ocorrentes na tradução da literatura de autoria indigena para a Lingua Nacional. Paper presented in the I Seminar of Indigenous Authorship Production ( $\mathrm{I}^{\circ}$ Seminário de Produção de Literatura de Autoria Indígena). Belém, I974. Available at: http://www.silinternational.net/americas/brasil/ PUBLCNS/LING/CompTrad.pdf. Acessed in November Ioth 2007.

Gruzinski, Serge (2003). A Colonização do Imaginário - Sociedades indígenas e ocidentalização no México espanhol. São Paulo, Companhia das Letras.

Karnal, Leonardo (I998). Teatro da Fé-Representação religiosa no Brasil e no México. São Paulo, Editora Hucitec.

Le Goff, Jacques e Nora, Pierre (1976). A Aculturação. In: História: Novos Problemas. Rio de Janeiro, Francisco Alves Editora.

Leite, Serafim (1938). História da Companhia de Jesus no Brasil. Rio de Janeiro, Civilização Brasileira.

Mello e Souza, Laura de (I993). Inferno Atlântico: demonologia e colonização, São Paulo, Companhia das Letras.

Montero, Paula (1995). Entre o Mito e a História. Petrópolis. Ed. Vozes.

Navarro, Eduardo de Almeida (I999). Método Moderno de Tupi Antigo. São Paulo, Editora Vozes.
Navarro, Eduardo de Almeida (200I). The Translations of the First Texts to Tupi, the Classical Indian Language in Brazil, in "Crop 6», São Paulo, Humanitas.

Neves, Luis Felipe Baeta (1978). O Combate dos Soldados de Cristo na Terra dos Papagaios, Forense Universitária, Rio de Janeiro.

Nida, Eugene A. (I964). Toward a science of translating. Leiden, E. J. Brill.

Nóbrega, Pe. Manuel da (1988). Diálogo do Pe. Nóbrega sobre a conversão do gentio (I559). In Manuel da Nóbrega. Cartas do Brasil. Belo Horizonte/ São Paulo, Itatiaia/ Edusp.

Ortiz, Fernando (1940/1995). Cuban Counterpoint. Durham, North Carolina: Duke University Press.

Paiva, José Maria (1982). Colonização e Catequese, São Paulo, Autores Associados.

Pompa, Cristina (2003). Religião Como Tradução. Bauru, EDUSC.

- (200I). Profetas e santidades selvagens. Missionários e caraíbas no Brasil colonial. Revista Brasileira de História, vol.21, no.40, p.I89.

Rafael, Vicente L. (I988). Contracting Colonialism, Translation and Christian Conversion in Tagalog Society Under Early Spanish Rule. Cornell University Press.

Robinson, Douglas (1997). Translation and Empire: Postcolonial Theories Explained. St. Jerome Publishing.

Schwartz, Stuart (1988). Segredos internos - Engenhos $e$ escravos na sociedade colonial I550 - I835. São Paulo, Companhia das Letras.

Schleiermarcher, Friedrich (2004). «On the Different Methods of Translating» trans. Susan Bernofsky in Venuti, Lawrence (ed.). The Translation Studies Reader, New York and London, Routledge, 43:66.

Todorov, Tzvetan (1999). A conquista da América: $A$ questão do outro. São Paulo, Martins Fontes.

Vainfas, Ronaldo (1995). A Heresia dos Índios. São Paulo, Companhia das Letras.

Venuti, Lawrence (I995). The Translator's Invisibility. London, Routledge.

Vicente, Gil (1997). Auto da Barca do Inferno. São Paulo, Editora Klick. 